\title{
Translation of Present-Day Egyptian Slang into English
}

\author{
Mohamed Kamel Abdel-daem \\ Lecturer in English Literature
}

\begin{abstract}
In this article, I try to present an English translation of idiomatic expressions that emerged in Egypt during the first decade of the twenty-first century. This translation is achieved through semantic, rather than literal, interpretation. The slang items translated are often populated by the Egyptian media, cinema and literature. Thus, the article is considered a comparative overview of modern Egyptian artistic works, and how their discourse has been affected by socio-political background of Egypt today. Slang appears to be associated with the culture in which it is created, so I found it would be irrelevant (as well as difficult for a non-native speaker of English who is not used to English culture and habits) to transfer the Egyptian-Arabic words and expressions into culturally-base English slang; rather they have been translated into standard (formal or informal) English. This paper may be safely regarded as a minute contribution to the roughly limited number of attempts to translate slang.
\end{abstract}

\section{Introduction}

This study aims to show how source slang could be transferred into a target text. Explaining the meaning of a slang item and how it functions is completely different from its being a component of conversational situations recognized by most of the native speakers. Consequently, it is interesting to research the use of slang in order to determine if there are any difficulties in transferring slang from one language to another. Most of lexicographers and linguists have found it socially shameful to study slang as it is often related to disrespectful demeanor (Adams 2009: 32). For this reason, and probably for being continuously changeable and unintelligible, slang is not often easy to interpret by academic researchers; socio-cultural factors also add to the difficulty. This paper seeks to inform the English-speaking reader of the slang terms used by the turn-ofcentury Egyptian youth, and how such slang expressions have differed from, and stemmed from, colloquial or slang speech used in the previous modern era, or by former youth generation. A translator's attention is frequently directed to slang as it has its roots in the source culture to which he/she belongs. The street and the media are the main fields for the making of slang; to be more accurate, casual expressions are often produced by laymen and then taken in the media; the process may be reversed: a film, a T.V series, a Talk-Show programmes, the Facebook or even a literary work, may help populate a slang expression and introduce it to a group of people who come from a social class that is different from where it has been first originated. Thus, the study tries to deal with dialogic (audio) source texts, or facets of a colloquial phenomenon in a genre of communication. The empirical acoustic examples rendered in this study are then turned into written English target texts.

There are numerous definitions of the term 'slang'; three are selected here. The Merriam-Webster Dictionary (MWD) defines slang as, thus:

1. "language peculiar to a particular group: as a : argot

$$
\text { : jargon" }
$$

2."an informal nonstandard vocabulary composed typically of coinages, arbitrarily changed words, and extravagant, forced, or facetious figures of speech".

The Cambridge Dictionary of American English (CDAE) gives the following definition:

$$
\begin{aligned}
& \text { "a very informal language that is } \\
& \text { used esp. in speech by particular } \\
& \text { groups of people and which } \\
& \text { sometimes includes words that } \\
& \text { are not polite". }
\end{aligned}
$$

Longman's Dictionary of Contemporary English (LDOCE) identifies slang as: 


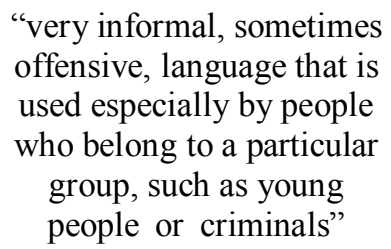

Almost all lexicographers agree that slang is casual, sometimes insolent, speech used within a certain human class, mostly teenagers or outcasts. What matters in the formation of slang is not the component terms, but how such words and phrases function; speaking in slang helps a person "to be creative, clear and acceptable to a select group" since "sharing and maintaining a constantly changing in-group vocabulary aids group solidarity and serves to include and exclude members" (Eble 1998: 19, 119).

\section{Methodology: Translation Strategy}

The translations presented in this paper are based on an ontological analysis. In other words, the source texts have been gathered by means of continuous observation of, and listening to, slang speech currently used in Egyptian down-to-earth settings, media, television dramas, movies, literary writings as well as blogs and internet chatting rooms. The study neither entails standard Arabic interpretations of the concerned slang samples, examines the impact of Egyptian slang on target text readers, nor refers to cultures other than that of modern Egypt.

The strategies employed in this analysis mark the functional role of translation by means of trying to reach a compromise between the non-identical source language $(\mathrm{S} \mathrm{L})$ and target language $(\mathrm{T} \mathrm{L})$ (Schjoldager 2008: 67,71). Henrik Gottlieb identifies several strategies for translating slang dialogues: Expansion, Paraphrase, Transfer, Imitation, Transcription, Dislocation, Condensation, Decimation, Deletion, Resignation ( Gottlieb 1992;1994). The glossary prepared in this study is chiefly based on the paraphrase strategy that “ alters a non-visualised expression in the ST such as a language-specific expression so that the TT conveys the same function with a significantly changed form" (Gottlieb 1992: 75). In items (5) and (21) below, the transcription strategy is used as it is "employed when facing anomalous speech such as nonstandard speech such as dialect or a pronunciation with a specific emphasis on a syllable" ( 1992:76); a pictorial illustration is also used in (5) to explain a culturally-based gesture. Imitation is taken in (25) " inta herkleez?" to transfer a proper noun. In (27), “ad-ak el-fanous" is rendered into English by depending both on paraphrase and expansion that explains a cultural allusion; literally it means "scratch the lamp" ( to refer to 'Alaa eddin's Lamp' in the Arabian Nights). This also applies to" mab-ye'rafsh" (30) which literally means "He never knows", but its reference to sexual impotence has been first used in cinema, in the late 1990s. The expressions" ya man" (13), " muz-za" (29), “systemak?” (32) and "ya-prens” (35) are Arabic transcriptions of " ..., man! ", "Ms”, “ your system?” and “ ...., Prince!” respectively.

\section{Translation of Slang Examples}

Many slangy expressions and terms emerged in today's Egypt ( from about 2000 to 2010, and a little afterwards); much of this jargon has been invented, and widely used, by and among young people; they come from various cultural environments. Their casual expressions are usually spread by the media as well as by bloggers on Facebook or Twitter. Each group of youth may have their private spoken code which they may or may not share with other teenagers and young men; hence, a word or phrase could lead to more than one interpretation. Here follows an attempt to translate these modern Egyptian vernacular words and phrases into English. Here, current Egyptian vernacular phrases or words are followed by Cairene transliterations, then by English translations.$$
1 \text { - " انت بتشتغلنى؟"/ " ده بيشغللك"/ " دى بتشتغلك"/ " اشتغله/ اشتغليه" }
$$$$
\text { "inta betishtaghalni ?"/ " da beyshtaghalak"/ " di betishtaghalak"/ "ishtaghaluh"/ "ishtaghaleeh" }
$$$$
1 \text { - “You bluff me?”/ "He's bluffing you."/ "She's bluffing you.", "Bluff him (to a male)."/ "Bluff him (to a }
$$
female)".

$$
\begin{aligned}
& 2 \text { - " فكك"/ " ياعم فكك"/ " فكنى منك/ منه/ منها"/ " فكك منه/ منها" } \\
& \text { "fokkak"/ "ya am fokkak"/ "fokkeni minnak/minnuh/minha"/ "fokkak minnuh/minha" }
\end{aligned}
$$

2 - "Don't care about it.”/ “ Man, don’t care about it.”/ " I care don’t about what you say or do/ he says or does/ she says or does."/ "Don't care about what he/she says or does."

$$
3
$$

"inta fasaltteni"/ "inta faseel moat" 
3 - "You took me out of mood."/ "You always take me out of mood."

"inta hatsaiahli ?”/ "saiahluh/ saiahiluh"

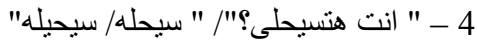

4 - "You're disclosing my (shameful) secret?"/ "Disclose his (shameful) secret (to a male)/ Disclose his (shameful) secret (to a female)."

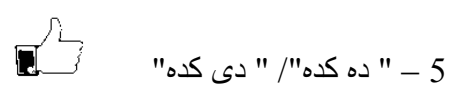

“da $\lambda$, $\lambda$

5 - "He/ It is very good"/ " She/ It is very good"

"da fai-yas"/ “ di fai-yasit”

6

6 - "He's exhausted(dead)/ It's broken down"/ "She's exhausted(dead)/It's broken down".

7 - "قفش على"/ "قفشت عليه/عليها" / " شكله (ده) قافش"

"afash alai-ya"/ " afasht aleih/ aleiha"/ "shakluh (da) afesh"

7 - "He got angry with me"/ "I got angry with him/her"/ "He seems angry"

"ya am da battikh"/ "da aiem fi maiet el-battikh"

8

8 - "He's an idiot( stupid)"/ "He understands nothing"

$$
9 \text { - "دا احنا اتزنجفا فالأمتحان النهارده"/ "زنجفة"/ "عزمنا فلان عندناو زنجفنا مشاريب" }
$$

"da ihna itzangifna fil imtihan en-naharda"/ "zangafah"/ " azamna flan andina wi zangifna meshareeb"

9 - "We've suffered from that difficult exam today"/ " demotic impudence (usually in public) OR "elite impudence (usually indirect)"/ "We were hospitable hosts, (offering good drinks)"

"el-hal (da) me-ashfat”

10

10 - “We've no ..."'/'I'm/ He's moneyless"

$$
11 \text { - "هنضرب"/ "هضربلى حاجه"/ "انا لسه ضارب فول عالصبح" }
$$

" hanid-rab"/ "had-rably haga"/ ana lis-sa darib fool a' sobh"

11 - "Let's start nobbling"/ "I'll have something (food or drink or smoking"/ "I've just had beans for breakfast"

"ana harooh azrufli sandwich fool"

12 - " انا هروح أظرفلى سندوتش فول"

12 - "I'll go and have a bean sandwich"

13 - " قشطه"/ "قشطه عليك/ عليه/ يمان"

" ishta"/ "ishta aleik/ aleih/ ya man"

13 - "It's wonderful"/ " You're (He's) lucky"/ "Great work (idea)"

"mihai-yis"/ "da tah-yees"

14

14 - "He's hallucinating/ a hallucinant"/ "It's hallucination"

"rewish/rewish than/ "rawshanah"

15 - "روش/ روش طحن/ "روشنة" 
15 - " He's cheerful/ a casual ( easy-going OR casually dressed)/ He's such a casual/ "casual dressing or behavior/ cheerfulness “

$$
16 \text { - " هنفخك"/ ده هينفخنى" }
$$

"hanfukhak"/ "da ha-yunfukhni"

16 - "I'll punish you "/ "He'll punish me"

"di koasa”

$$
17
$$

17 - "It's favouritism (unfair/ unjust/ inequality) “

"har-talah"/ da biyhar-tel"

$$
18 \text { - " هرتلة"/ ده بيهرنل" }
$$

18 - "It's a heresy/ nonsense"/ " He's saying a heresy OR nonsense OR babbling”

" da bi-ysa'at"/ "inta bit-sa'at?"/ "da bainluh bi-ysa'at"

19 - " ده بيسقط"/ "انت بتسقط؟" / " ده باينله مسقط"

19 - "He misses words while speaking/ He's had a drop too much"/ "You miss utterances?"/ "He seems drunk and is dropping off "

$$
20 \text { - " احلقله/ نفضله/ ادلقه" / " كبر (الجمجمة)(الجى)" }
$$

“ eh-la'luh/ naffadluh/ udlu’uh"/ "kab-bar (il-gumguma) (ej-ji)"

20 - "Drop what he says ( Don't care about what he says" / " Put your mind at rest / Take it easy / Don't care about this"

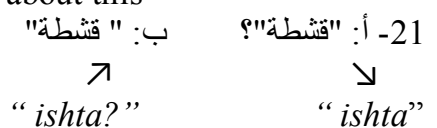

21 - A: "Do you agree/ You're OK?" $\quad$ B: Yes, Ido/ It's all right”

"tat-neesh/tas-ee'a/ hi-la'a/ tak-beer/alb”

22 - " indifference"

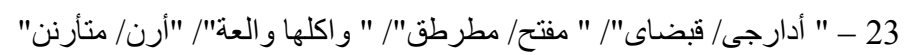

"adargi/ abadai"/ "mifat-tah/mit-tarta' " wakilha wal 'a"/ "aran/ mit-arnan"

23 - "thug"/ " cautious, clever"/ " cunning, greedy"/ " arrogant (conceited)"

24

"amblayez"/ "sik-ka"/ "bashka"/ "a-aw-wis"

24 - "in vain"/ "unlawful solution( way)"/ " (your) cards are on the table"/ " (I) study"

25 - " استكانيس" / " مستكنيس" / "انت هر كليز؟"/ "حبشتكانات" / " شخلفة"

“estikanayis"/ "mestikanyas"/" inta herkleez?"/ "habash-takanat" /"shakhlafa"

25 - " a time of rest"/ " having a rest"/ "You're Hercules?( irony)"/ " talking sophisticatedly or in standard style" / " gaily enjoying one's time"

$$
26 \text { - " فى الأستخبس( فى الخباسة)" / " عامل دماغ"/ " هارش ...؟"/ " " مأنتخ/ أنتخة" }
$$

"fi el-ostukhebs (fil-khabasa)"/ aamil dimagh"/ haresh ...?"/ mi-antakh/antakha"

26 - " secretly"/ " drugged (drunk)"/ "You understand ...?"/ "workless / worklessness"

“ad-ak el-fanous (zoa' agalak)"/ " erkab el-fard"/ "eih el-asatik?"

27 - "Off you go / go away"/ " Get ready to leave at once"/ "What's going on?( How are things?)"

$$
28 \text { - " طيب أنا هرلب على (مكان) و أشق"/ " أنا هركب فرد بقه حالا و أهبو على على بره" }
$$

"ta-yeb ana hahlib ala (makan) wa ashoa"'/ ana harkab fard ba'a halan wa ahboa' ala bar-ra"

28 - "I'll go [ place] and be back quickly"/ "I'm going to go out now"

$$
29 \text { - " مزة (أوزى)"/ " المزة بتاعتى" / " دى بقت مزة" }
$$

“"muz-za (ouzi)”/ "elmuz-za beta'ti”/ "di ba-it muz-za” 
29 - " a girl who is pretty and buxom"/ " my beloved or girlfriend"/ "She's grown into an adorable teen girl"

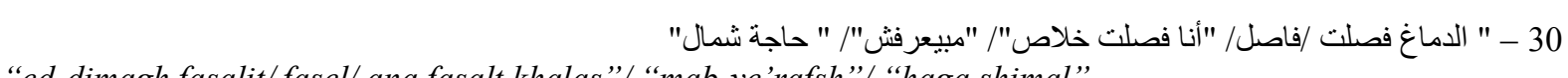
"ed-dimagh fasalit/fasel/ ana fasalt khalas"/ "mab-ye'rafsh"/ "haga shimal"

30 - “I'm (He's) no longer on drugs [ in bad need of doing drugs ]/ I'm not able to concentrate or go on"/ "He's impotent"/ "something unlawful"

$$
31 \text { - " انزل من على ودنى"/ " فاصل"/ " نركب رجلينا"/ " بستفة/ انا بستفته" }
$$

"inzel min ala wedni"/ "fasel"/ nerkab reglaina"/ "bastafa"/ "ana bastiftoh"

31 - "Stop talking about it"/ "insane/ drunk/ drugged"/ "Let's walk"/ " rebuke / I rebuked him"

$$
32 \text { - " دا انا هاخرتأك/ خرتأه/ انا خرتأت فلان/ اتخرتأ"/ " انت ايه سستمك؟" }
$$

"da ana ha-kharta'ak/kharta'ah/ana kharta'at folan/itkharta"”/ "inta eih systemak?"

32 - "I'll beat you/ beating/ I beat somebody/ He was beaten [ often in video games]"/ "What's you attitude or reaction?/ How will you act?"

$$
33 \text { - " كل و احد يلم تعابينه و يلعب قدام بيته عشان هنرشرش ميه" / " منفض" / "فاصل " }
$$

" kull wahed yel-lem ta'abeenuh wi-yel-ab ud-dam baituh ashan han-rashrash may-yah"/ "minaf-fad") "fasel" 33 - "Let' stop working (it's time to go home, everybody)/ Mind your own business, everybody[ threat]"/ " being in a state of caring about nothing"/ "careless , clumsy"

$$
34 \text { - "شهيصنى"/ " انا هارسيك عالحوار كله"/ " ياعم رووش" }
$$

"shahayasni"/ "ana haras-seek 'al- hiwar kul-luh"/ "ya am raw-wish"

34 - "Please me"/ "I'll tell you the whole( true) story"/ " Enjoy yourself/ Take it easy"

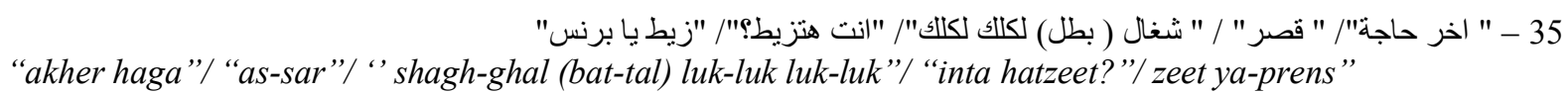

35 - " extremely"/ "cut it short"/ "You're (stop) talking too much"/ "You're making a mess( breaking the rules)?"/ "Enjoy yourself, guy”

"da wad sees/ doal e-yal sees"

$$
36 \text { - " ده و اد سيس/ دول عيال سيس" }
$$

36 - "He's a soft, impotent guy/ They're soft, impotent guys"

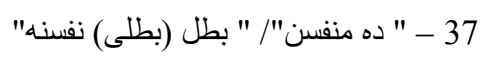

" da minafsin"/ " bat-tal(bat-tali) nafsanah"

37 - "He's jealous/ spiteful”/ "Stop this jealousy/ spite"

\section{Conclusion}

In conclusion, slang - as well as colloquial speech - is often determined by socio-political and economic and cultural changes that take place at any given real setting (Newmark 1998:37-8). The dialect items above, which are rendered into English, obviously reflect all aspects in the Egyptian arena during the pre- 2011Revolution era. This will open gates for scrutinizing different discourses, through cinema, media, literature, etc., in Egypt and other 'Arab Spring' countries.

\section{Bibliography}

[1]. Adams, Michael. Slang - The People's Poetry. Indianapolis, Indiana: Oxford Press,2009

[2]. Eble, Connie. Slang and Sociability - In-group Language among College Students. Chapel Hill and London: The University of North Carolina Press, 1996

[3]. Enani, M. On Translating Arabic : A Cultural Approach, GEBO, 2000.

[4]. - ------ , (2001). English-Arabic Translation, An Introduction. Cairo: Anglo Egyptian Bookshop.

[5]. Farag, Sameh. Mo'jam Farag lil-Amiya Al-masriya (Farag's Glossary of Egyptian Vernacular).

[6]. Cairo: GEBO, 2006

[7]. Gottlieb, Henrik . Subtitling - A New University Discipline. In: Dollerup, Cay and Ladegaard, Anne(red). Teaching Translation and Interpreting - Training, Talent and Experience. Amsterdam/Philadelphia:John Benjamins Publishing Company, 1992

[8]. - -------- Tekstning - Synkronbilledmedieoverscettelse. Copenhagen: Center for Oversættelse, Københavns Universitet, 1994

[9]. Hatim. B. and Mason. I. (1990) Discourse and the Translator. London: Longman.

[10]. Kelly, D. (2005). A handbook for translator trainers: A guide to reflective practice. Manchester, UK: St. Jerome. 
[11]. Massoud, M.,F.,(1988). Translate to Communicate, A Guide for Translators. New York: Library of Congress Cataloging-inPublication Data.

[12]. Newmark, Peter. More Paragraphs on Translation. England: Multilingual Matters Ltd, 1998

[13]. Vanessa W. "How Different is Egyptian Arabic from Modern Standard Arabic?". http://www.arabacademy.com/en/blog/2010/

[14]. Schjoldager, Anne. Understanding Translation. Aarhus: Academica, 2008

\section{Dictionaries}

[15]. Al-mu'jam Al-wasset (Intermediate Arabic-Arabic Dictionary). Cairo: Academy of Arabic Language, 1998

[16]. The Cambridge Dictionary of American English. U.K: CUP, 2000

[17]. Longman Dictionary of Contemporary English, Longman, 2010

[18]. The Merriam-Webster Dictionary. U.S: Merriam-Webster Inc.,2011

[19]. Oxford English Dictionary, $3^{\text {rd }}$ ed. OUP, 2011 